\title{
Envia teu espírito e haverá criação ${ }^{1}$
}

\begin{abstract}
Resumo
Quero colaborar com este número da Revista de Interpretação Bíblica Latino Americana (RIBLA) a partir de meus estudos teológicos e bíblicos, mas, sobretudo, a partir da minha convivência com as populações tradicionais da foz do rio Amazonas: quilombolas, ribeirinhos, índios, com os quais celebro a Palavra. Entrar na bíblia a partir das culturas ancestrais latino-americanas fez aparecer mais evidente quais são as "coisas" que o Pai quis revelar aos pequenininhos e fez questão de esconder aos sábios e entendidos e, quem sabe, também, aos teólogos (Mt 11, 25-26).
\end{abstract}

\begin{abstract}
Abstrac
I want to collaborate with this issue of the Latin American Biblical Interpretation Magazine (RIBLA) from my theological and biblical studies, but, above all, from my coexistence with the traditional populations of the mouth of the Amazon River: Quilombolas, riparian, Indians, with which I celebrate the Word. Entering the bible from Latin American ancestral cultures made it more evident what "things" the Father wanted to reveal to the little ones and made a point of hiding from the wise and knowledgeable, and perhaps also from theologians (Mt 11, 25-26).
\end{abstract}

\section{Uma espiritualidade ecocentrada}

Espiritualidade é a obra, o sopro, a vida do Espírito de Deus em nós e em tudo que existe, desde que tudo começou, quando "o sopro de Elohim ${ }^{2}$ estava tranquilo diante das águas" (Gn 1,2). Para experimentar e viver esta força do Espírito precisamos desconstruir leituras, reinterpretar palavras, tirar véus e paredes que os entendidos levantaram para esconder as "coisas do Pai". Conheceremos e experimentaremos, assim, como o Espírito de Deus fecunda e gera a nossa "espiritualidade".

\footnotetext{
${ }^{1}$ Este ensaio é fruto da sistematização de vários outros escritos meus, ao longo destes últimos anos. Foi publicado no Theological Journal Voices, n. XXXVII, abril-setembro 2014; «Deep Ecology, Spirituality and Liberation». 434 pp. Sito internet: eatwot.net/VOICES/VOICES-2014-2\&3.pdf

${ }^{2}$ No lugar de usar a costumeira tradução "Deus", prefiro manter a palavra hebraica Elohim com seu sentido singular e plural ao mesmo tempo. Seria algo como "Toda a divindade" e que se aplica a todas as maneiras com que nos é dado experimentar e conhecer a divindade mantenedora da vida.
} 
Vamos começar pelas primeiras páginas da bíblia, as páginas que todos conhecem e que se tornaram os pilares de uma civilização que, muitas vezes, foi de morte.

\subsection{Re-lendo a primeira parábola da criação}

A chamada cultura ocidental, de matriz grega, caiu na armadilha de pensar que a tarefa que Deus dá ao ser humano de "submeter a terra e dominar sobre os peixes do mar e sobre as aves dos céus e sobre todo animal que se move sobre a terra." (Gn 1,28), significa que o homem³, imagem de Deus, é, como Deus, o dono de tudo, o elemento mais importante da natureza, o centro da criação. Movidos por esta "teo-ideologia", acabamos por teorizar que tudo que existe tem sentido quando orientado para nós e que nós podemos fazer com a natureza tudo o que quisermos.

Em nome deste domínio, o homem "submeteu a terra", devastou o ambiente, poluiu as águas, matou os animais, sem alguma razão e causou a morte.

"Submeter a terra" legitimou a propriedade privada, a concentração das riquezas e a violência exploradora e assassina de todas as vidas.

Em todos os mitos ancestrais dos povos originários da Amazônia, pelo contrário, a ação criadora do/s deus / es é sempre uma ação que quebra e vence situações de morte e de sofrimento. É a presença da vida que supera e derrota a presença da morte.

É, exatamente, o mesmo que nos diz a primeira página da Bíblia.

Nada tem a ver com a visão filosófica europeia, na qual os cristãos foram quase sempre catequizados e que define criação como "fazer do nada todas as coisas", afirmando, assim, a total separação entre Deus e todas as coisas e o seu domínio sobre tudo que existe.

Uma tradução incomum, mas literalmente possível, do primeiro versículo da Bíblia, pode abrir horizontes e significados: No princípio criou Elohim com os céus e com a terra (Gn 1,1): Céus e terra participam como co-criadores desta ação de vida.

A palavra de Elohim é geradora de vida. Do outro lado está a morte, estão o deserto, as trevas e as águas do abismo: as forças caóticas simbólicas da morte (Gn 1,2).

"Viva a luz e viveu luz... Viva uma expansão entre as águas e viveu ... E assim viveu..." (Gn 1,3.6.7.9).

\footnotetext{
${ }^{3}$ Uso de propósito, a palavra homem, no masculino, porque esta ideologia greco-ocidental, não considera a mulher como sujeito filosófico.
} 
Viver: hyh / hayah ${ }^{4}$ como ser, acontecer. Um verbo que se repete 27 vezes em Gn 1 . O verbo que é o radical do nome de Yahweh: o vivente que faz viver.

A mesma "alma vivente" que faz viver Adam (Gn 2,7) faz viver os filhos das águas (Gn 1,20s), os filhos da terra (Gn 1,24) e todos, igualmente, recebem a bênção de Elohim de gerar vida: "Frutificai e multiplicai-vos" (Gn 1,22.28).

A parábola da criação de Gn 1, então, longe de ser uma fábula nostálgica de um passado definitivamente perdido, é memória da luta criadora e re-criadora permanente em defesa do "bom" que é tudo o que vive, contra todas as forças caóticas de morte que teimam em transformar a vida em trevas e deserto.

Desde o princípio - assim proclama esta página - Elohim se manifesta com seu poder vencedor. Nos três primeiros "dias" canta-se a vitória de Elohim contra todos os "males", simbolizados pelas trevas, pelas águas do abismo e pelo deserto.

A ação criadora de Elohim que "separa" as trevas da luz, as águas de cima das águas de baixo, a terra dos mares, transformando o deserto em prados e florestas, revela aos pobres e aos oprimidos que vale a pena confiar neste Elohim capaz de derrotar todas as forças caóticas que produzem o medo e a morte.

A vitória de Elohim se completa, nos outros três "dias", quando, após fazer viver a luz, o firmamento e a terra fértil, ele garante sua continuidade, criando os "exércitos" da luz, das águas, dos ares e da terra. Apesar da conotação negativa e violenta que esta palavra tem para nós latino-americanos, usamos a palavra bíblica "exércitos" (Gn 2,1) porque indica que as criaturas que povoam a natureza terão a incumbência de cuidar, de zelar e de defendê-la, combatendo até o fim dos tempos, contra todas as formas de morte.

Caberá ao sol, á lua e às estrelas cuidar e zelar pela vida da luz; aos seres marinhos caberá zelar pela vida das águas; da vida dos ares cuidarão os pássaros do céu e os animais deverão tomar conta da vida do solo fértil.

A criação do ser humano - homem e mulher - feito à imagem e semelhança de Elohim, tornará toda a obra de Elohim boa, muito boa, pronta para continuar sendo, para todo o sempre, boa, muito boa. Os exércitos de Elohim, assim completos, farão com que a vitória de Elohim sobre as trevas, os abismos e os desertos, possa continuar ao longo da história. Os "exércitos" de Elohim, guiados pelo ser humano, cuidarão para que trevas, abismos e desertos nunca mais voltem a vencer.

"Submeter a terra" nos obriga, então, a cuidar e zelar por esta nossa casa comum e por tudo que nela habita com a mesma paixão criadora e

\footnotetext{
${ }^{4}$ A leitura hieroglífica destas letras nos diz que h é o símbolo da vida, do ser, do que anima e y é o símbolo da potencialidade, da duração, do se manifestar. $O$ verbo hyh então simboliza a vida que se manifesta e se potencializa na vida.
} 
amorosa de Elohim, em vista da felicidade de todas as pessoas e de todos os seres vivos.

Como Elohim, com a presença de seu espírito, nós, homens e mulheres, devemos continuar sua obra criadora, lutando contra todos os males que ameaçam a vida de todos e do planeta, contra a violência presente em todas as páginas da história humana. É um permanente processo de criação e re-criação que só terminará quando poderemos viver sem mais dor e luto nos novos céus e na nova terra, na "terra sem males" que todos queremos.

\subsection{Re-lendo a segunda parábola da criação}

A segunda parábola da criação (Gn 2,4b-25) nos fala da relação de Adam com Yahweh Elohim e com o jardim das delícias / Éden.

Novamente encontramos uma situação inicial de não vida, de deserto.

Na primeira parábola o elemento vital era o "sopro de Deus" sobre as águas. Agora é o "vapor", que, hieroglificamente, indica uma "força em movimento" que encharca a adamah ${ }^{5}$, a terra enquanto geradora de vida (Gn 2,6).

Da adamah Yahweh Elohim forma Adam que "vive como alma vivente" pelo alento de vida (Gn 2,7); da adamah Yahweh Elohim faz brotar toda árvore (Gn 2,9); da adamah Yahweh Elohim forma tudo o que vive no campo e nos céus (Gn 2,19).

Tudo que vive tem um único pai e uma única mãe: uma única vida em todas as suas diferentes formas.

Dois verbos definem esta relação com o jardim: Adam é colocado no jardim para `abad = servir, prestar culto e para shamar = observar, obedecer, guardar $(\mathrm{Gn} 2,15)^{6}$. Estes mesmos verbos que, em muitos outros textos, definem a nossa relação com Deus, aqui, definem, também, a nossa relação com o jardim, com a adamah, com a terra. Adam não é o dono do jardim: é o servo obediente.

Quando tudo começou, ainda não havia vida porque nem Yahweh Elohim tinha feito chover, nem havia Adam para "servir a terra" (Gn 2,5). É desta relação de serviço e de obediência que pode nascer e se sustentar a vida

Na primeira parábola é Elohim que dá o nome a todas as realidades de vida quando são criadas: dia e noite, firmamento, terra e mar (Gn 1,5.8.10). Nesta segunda parábola é Adam que dá o nome a todas as almas viventes (Gn 2,19-20). É o compromisso de quem conhece, cuida e se responsabiliza, como um pai que dá o nome ao filho recém-nascido.

\footnotetext{
${ }^{5}$ A palavra Adamah contem a palavra dam $=$ sangue. Sangue da terra, terra fértil, geradora de vida.

${ }^{6}$ Nossas bíblias, quase sempre, preferem usar a tradução da bíblia grega (LXX): "cultivar e guardar".
} 
E, contra toda arrogância antropo-cêntrica de nossa filosofia greco-ocidental, esta página nos propõe uma relação eco-cêntrica, ao proclamar que o Adam sozinho não é bom. A imagem de Deus precisa se relacionar com o jardim, com as árvores e com todos os seres vivos. E reconhece na mulher a sua mesma identidade, seu mesmo nome: ele a reconhece exatamente igual a si, diante de si: substância de minha substância, carne de minha carne (Gn 2,23).

A proximidade desta cosmovisão bíblica com a cosmovisão dos mitos dos indígenas e dos afro-descendentes é evidente. Ler a bíblia com os povos da Amazônia é a possibilidade que o biblista tem de se aproximar com maior facilidade do sentido originário das palavras do gênesis.

Como é difícil alcançar esta proximidade quando a bíblia é lida nas academias e até nas nossas liturgias!

\subsection{Re-lendo a parábola da árvore das vidas e do conhecimento do bem e do mal}

A interpretação que nossas comunidades costumam fazer desta página nos leva a aplicar o paradigma do crime-castigo. Um crime tão grande que marcou um castigo para todas as gerações: o pecado original. Um pecado do qual só foi isenta a virgem Maria e, evidentemente, seu filho Jesus, cujo sangue derramado aplacou a ira do Pai e nos lavou de nossas culpas, mas não de nosso corpo de morte. A morte é o castigo definitivo, a inevitável consequência do pecado de Adam e de sua mulher.

Uma leitura a partir dos povos da Amazônia, porém, nos conduz por um caminho mais amplo e menos moralista e condenatório. A terra onde estão sepultados os ancestrais é terra sagrada, é terra santa, fonte de vida: essencial para recuperar as forças vitais.

A parábola nos fala do homem e da mulher que quebram as relações de serviço e de obediência porque querem se afastar da terra para ser como Yahweh Elohim ${ }^{7}$. A "tentação" é ser como Deus: justamente o que sugeria a leitura equivocada do "submeter a terra" da primeira parábola. Querer ser como Deus é querer ser o dono de tudo. Esta é a causa de todos os males.

O "castigo" é voltar a servir à vida, é voltar a servir a terra. Será com dor e será com fadiga, mas o encontro com a terra será sempre vivificador.

Até que voltes à terra, porque dela foste tomado; porque tu és pó e em pó voltarás. $(\mathrm{Gn} 3,19)$

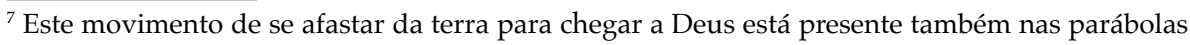
do dilúvio e da torre de Babel. Também nestas parábolas a volta para a terra é elemento vivificador.
} 
Voltar, retornar: $s h u b^{8}$. Converter-se: é o mesmo verbo. Converter-se a Deus e converter-se à terra. Voltar a servir e a obedecer; voltar à vida no sentido mais pleno. Não existe a palavra morte nas palavras de Yahweh Elohim.

O versículo seguinte é decisivo: é a chave de leitura do "castigo":

E chamou Adam o nome de sua mulher havah / vida/ Eva; porque vive a mãe de todos os viventes. $(\mathrm{Gn} 3,20)$

Só agora, neste momento que podia parecer de morte, Adam consegue dar um nome à sua mulher: Vida! Adam vai levar consigo a vida para fora do jardim. No conhecimento da mulher e no servir terra, a vida poderá continuar até que tenhamos novos céus e nova terra e nunca mais haverá lágrimas e dor.

E Yahweh Elohim o enviou fora do jardim do Éden para servir a terra da qual foi tirado. (Gn 3,23)

E conheceu Adam a Vida, sua mulher e ela concebeu. (Gn 4,1).

\subsection{Bendizei ao Senhor, todas as obras do Senhor}

Os céus narram a glória de Deus, o firmamento anuncia a obra de suas mãos (S1 19,1).

Todos nós que celebramos com hinos e salmos ao nosso Deus, fazemos quotidianamente a experiência de convocar a criação toda para aclamar e proclamar as maravilhas do nosso Deus, celebrar sua glória, manifestar seu poder e seu reinado. Tudo que existe proclama: "Teu reino é reino de todos os séculos, teu domínio se estende a todas as gerações" (S1 145, 13). "De Yahweh é a terra com o que ela contém, o universo e os que nele habitam" (S1 24,1-2).

A criação toda é viva: os montes pulam, os rios batem palmas, as tempestades revelam o nosso Deus.

Impressiona o cântico dos três rapazes jogados pelo imperador na fornalha ardente (Dn 3,57-90 LXX). Escrito em grego, este texto confronta o modelo grego de ecologia e economia que pretendia se impor a toda a oikoumene mediterrânea: uma natureza inanimada, pura matéria, cujos recursos inesgotáveis deviam ser explorados para gerar riquezas em prol dos mais fortes. A criação, pelo contrário, é viva, é animada e participa da grande louvação: Bendizei o Senhor, celebrai-o e exaltai-o para sempre!

É assim no turé, uma dança típica dos nossos índios: tudo o que existe e vive é chamado a entrar na roda, a participar da única festa do povo, a se fazer uma coisa só conosco, penetrando na vida dos que dançam e

\footnotetext{
${ }^{8}$ A simbologia hieroglífica destas letras é conhecimento para dentro que faz a unidade $=$ recons-
} trução da tua identidade. 
festejam. É assim nos terreiros do candomblé e da umbanda: tudo é vida, tudo é interação: céus e terra se encontram, se fecundam, produzem e se reproduzem num processo permanente de criação. Assim é na Bíblia.

Terra santa, tempos santos, comunidade santa: uma trindade indivisível que experimenta a circulação de uma única vida, a do Espírito!

Os tempos da natureza são tempos santos: novilúnios, semeaduras, colheitas, vindimas, cios das ovelhas, primícias, vinho novo, azeite perfumado, tudo vira festa, marcando os tempos, os ritmos deste útero fecundo e gerador, os gestos sagrados de um povo que celebra seu Elohim/ deus(es), singular e plural ao mesmo tempo.

Precisamos nos libertar da visão economicista que - seja ela capitalista ou socialista - considera a natureza "matéria prima" que só adquire valor quando transformada em mercadoria, em riqueza.

Se Deus colocou tudo aos nossos pés é para que seja manifesto quão grande é o nome de Deus em toda a terra e quanto Ele nos ama (Sl 8,3-9).

Esta é a raiz de uma espiritualidade profunda. Esta espiritualidade significa entrar em sintonia, em comunhão holística, com a ação do Espírito de Deus que, desde que tudo começou, continua criando e renovando a face da terra: "Envia teu espírito e haverá criação e renovas a face da terra" (S1 104,30).

\section{Espiritualidade eco-centrada é espiritualidade cristã}

Na arrogância de nossa cultura ocidental, a nossa lógica racionalista nos levou a usar palavras de conotação negativa, para falar desta cosmovisão comum às populações tradicionais: sincretismo, politeísmo, panteísmo, animismo, pois elas acreditam que todas as coisas e todos os seres têm "alma/vida", a mesma vida de Deus.

Na melhor das hipóteses, chegamos a dizer que estas páginas bíblicas são narrativas "míticas", próprias do "antigo" testamento e que devem ser superadas pela perspectiva racional, revelada no "novo" testamento.

Precisamos aprofundar: esta espiritualidade é compatível com a espiritualidade cristã? Qual seria o lugar de Jesus na espiritualidade ecocentrada?

Vamos voltar à afirmação de Gn 1,27: "E criou Deus o homem à sua imagem: à imagem de Deus o criou; homem e mulher os criou". Ou, como recorda Gn 5,1-2 questionando nosso machismo congênito: "Quando Deus criou o ser humano, ele o criou à semelhança de Deus. Criou-os homem e mulher, e os abençoou. E no dia em que os criou, Deus os chamou de Adão".

A plena compreensão destas palavras e, por isso, da nossa missão de "imagens de Deus", só é possível a partir de Jesus, a mais autêntica e completa "imagem de Deus". Como nos disse a carta aos Colossenses: 
"Ele é imagem do Deus invisivel, o primogênito de toda a criação; pois é nele que foram criadas todas as coisas nos céus e na terra. Tudo foi criado por ele e para ele. Ele existe antes de todas as coisas e nele todas as coisas têm consistência" (Col $1,15-17)$.

A "única" vida que perpassa tudo que existe é a vida de Cristo. É o que repete, também, o evangelho de João que se abre com a afirmação do novo gênesis, num claro paralelismo com a primeira página da Bíblia:

"Todas as coisas foram feitas por ele e sem ele nada do que foi feito se fez" (Jo 1,3).

Dominar a terra, então, significa fazer com que toda a criação participe do plano amoroso que Deus tinha quando criou tudo que existe:

"Colocar Cristo como cabeça de tudo o que existe no céu e na terra" (Ef 1,10).

Submeter a terra significa, assim, conduzir tudo e todos a Jesus, ao seu Reino de vida e de luz, no qual todas e todos tenhamos a vida, a paz, a abundância, sem distinção de raça, de credos, de classes sociais e nem das nomenclaturas científicas.

É o que a criação toda espera de nós que, com Cristo, em Cristo e por Cristo, somos a imagem de Deus na terra.

"A criação espera ansiosamente a revelação dos filhos de Deus" $(\operatorname{Rm} 8,19)$.

Assim saberemos que o gemido de dor da criação é, na realidade, um gemido de parto ( $\operatorname{Rm} 8,22)$, sinal supremo de vida e de invencível esperança (Jo 16,2-22).

Na contramão do pensamento greco-romano que afirmava ser a natureza algo totalmente inanimado e, por isso, subordinada aos interesses dos humanos racionais, a carta aos Romanos afirma que a criação está indissoluvelmente ligada aos seres humanos: conosco ela geme, conosco ela espera, conosco ela anseia, conosco ela sofre. No horizonte da humanidade e da criação está a mesma esperança de serem libertados da "escravidão da corrupção ${ }^{9}$, em vista da liberdade que é a glória dos filhos de Deus" $(\operatorname{Rm} 8,21)$.

O Espírito que, desde o princípio, está na origem da vida, une seus gemidos aos nossos gemidos e aos gemidos da criação e vem em socorro da nossa fraqueza, diante de um desafio tão grande ( $\operatorname{Rm} 8,26-27)$.

As comunidades eclesiais, alimentadas pela certeza que tudo "concorre para o bem dos que amam a Deus" (Rm 8,28), deverão sempre ser as testemunhas do ressuscitado, viver segundo a "nova criatura", buscando sempre, em primeiro lugar o reino de Deus e a sua justiça, contra os falsos reinos geradores de injustiça e de morte.

${ }^{9} \mathrm{O}$ termo grego ftorá significa, sobretudo, destruição, ruína, aniquilamento, devastação. 
É o que o Espírito nos impele a fazer. Lutar, como Jesus, em favor da vida, contra todas as forças caóticas da morte e da exclusão, buscando fazer com que a criação toda possa alcançar a plenitude da vida que nela é contida.

Neste texto (Rm 8,19-26), a criação, os filhos de Deus e o Espírito, também, formam uma espécie de trindade, na qual os três elementos formam uma única realidade, na construção da liberdade dos filhos de Deus que significa a liberdade de toda a criação. Hoje a ciência, também, vem confirmando esta visão holística que Paulo e João, fiéis à cosmovisão semita, proclamavam, na contramão do pensamento lógico grego.

\section{Deus criador, Deus de todos os pobres}

A outra questão que provoca esta reflexão é decisiva, sobretudo, na América Latina: $\mathrm{O}$ que têm a se dizer mutuamente a ecologia profunda e a espiritualidade da libertação?

Na memória dos povos da Amazônia a divindade é sempre o Pai da bênção e da promessa, da vida. Herdeiros de uma longa história de brutal exploração, eles recorrem à divindade, a santos, orixás, benzedores, pajés, mães de santo, pois, guardam a certeza, celebrada, também, em inúmeros salmos, que Deus cuida deles, faz justiça, não abandona os que nele confiam.

A memória do Elohim criador da natureza, de tudo que existe, não deve ser, em hipótese alguma, separada da memória do Yahweh salvador dos pobres e dos oprimidos.

Bem-aventurado aquele cuja esperança está em Yahweh, seu Elohim, que fez os céus e a terra, o mar e tudo o que neles há e mantém para sempre a sua fidelidade.

Que faz justiça aos oprimidos e dá pão aos que têm fome.

Yahweh liberta os encarcerados. Yahweh abre os olhos aos cegos,

Yahweh levanta os abatidos, Yahweh ama os justos.

Yahweh guarda o peregrino, ampara o órfão e a viúva, porém transtorna o caminho dos ímpios.

Yahweh reina para sempre; o teu Elohim, ó Sião, reina de geração em geração. Aleluia! (S1 145,5-10 e inúmeros outros salmos. Ver, também, Jd 9,11-12)

Usar a narrativa da criação para justificar a dominação sobre a natureza e sobre os outros seres humanos será, sempre, uma blasfêmia.

Não podemos esquecer que a primeira página da Gênesis encontra, possivelmente, sua origem literária nos capítulos 40-55 do livro de Isaias, conhecido como Segundo Isaias ${ }^{10}$. Estas páginas nasceram nos momentos

\footnotetext{
${ }^{10}$ A vitória de Deus contra trevas, águas, abismos e desertos, as forças caóticas da morte, está presente de maneira significativa, no Segundo Isaias (Is 42,$7 ; 43,2 ; 43,16 ; 44,3 ; 44,4 ; 45,7 ; 48,21$; 49,$9 ; 50,2 ; 51,3 ; 51,10$ ) Diga-se o mesmo da palavra tohu / caos. O mítico adversário das origens,
} 
difíceis em que escravos e escravas, viviam oprimidos no cativeiro em Babilônia.

Foi deste grupo de excluídos e excluídas que surgiu a boa notícia. Lá, do fundo do poço, surgiu uma teologia com dimensões completamente novas, inauditas, mas que vinha acontecendo desde o princípio, desde sempre (Is 41,26; 43,19).

É o anúncio do Deus Criador, da grande mãe, a única mãe geradora da vida de todos e de tudo: "Eu te formei,... eu te fiz,... eu te criei,... eu te modelei,... eu te tomo pela mão,... eu te ajudo,... eu estou contigo, ... eu te dou forças,... ".

Nestas páginas, Deus deixa de ser somente o Deus de Israel. Deus é Deus de todos, até dos filhos sem família, dos sem genealogia, dos sem povo, das culturas oprimidas, excluídas, marginalizadas (Is 45,9-12). Todos são filhos dele, também os não judeus, filhos da violência, da guerra e da deportação (Is 45,23-24).

Nunca uma mensagem foi tão universal, tão abrangente, tão inclusiva!

Esta gente sofrida nos fala de um só Deus, mas com uma incrível quantidade de facetas. Tudo que é fonte de vida para o pobre cansado e desanimado é parte deste Deus que é único, mas que para cada um dos pobres assume um rosto diferente, capaz de gerar vida. Deus é único, não porque exclui, mas porque reúne em si mesmo todos os elementos de vida das religiões populares. Encontramos nele o Deus cananeu da chuva e do orvalho fecundante (Is 45,8; 55,10-11); o oleiro modelador da mitologia mesopotâmica (Is 45,9); o dominador dos mares agitados (Is 51,15) e, de maneira especial a deusa-mãe comum a todas as culturas semitas (Is 46,3$4 ; 49,15 ; 66,9-13)$. Pela primeira vez Deus é chamado de Pai:

Repara desde os céus e olha desde a tua santa e gloriosa morada: Onde estão o teu ciume e as tuas forças? O frêmito das tuas entranhas e das tuas misericórdias ${ }^{11}$ para comigo acabou? Porque tu és nosso Pai, quando Abraão não nos conhece, $e$ Israel não nos reconhece; tu, Yahweh, és nosso Pai; nosso Redentor desde a antiguidade é o teu nome. (Is 63,15-16)

É um Deus único, mas "completo": tudo que for elemento de vida, de segurança, de esperança para os pobres, ele reúne, ele soma, ele engloba numa só divindade, boa, materna, protetora, consoladora para toda esta gente sofrida: um único e completo Elohim. Os outros deuses não existem: se forem dos pobres, já estão contidos nele; se forem dos opressores, são ídolos, imagens, não são nada/tohu!

também, está muito presente nos textos do Segundo Isaias (Is 34,11; 40,17. 23; 41,29; 44,9; 45,18; $49,4)$. "Porque assim diz o Senhor, que criou os céus, o Deus que formou a terra, que a fez e a estabeleceu; que não a criou para ser um caos / tohu, mas para ser habitada: Eu sou o Senhor, e não há outro". (Is 45,18). Ver, também, GALLAZZI, Sandro. Por meio dele o desígnio de Deus há de triunfar. In RIBLA, vol. 21. Vozes, Petrópolis.

${ }^{11}$ Literalmente "úteros". É um Deus Mãe e, agora, Pai. 
Única imagem de Deus é Adam, a humanidade, no mesmo tempo imagem de Deus e produto da terra fértil/'adamah. Adam: homem e mulher, (Gn 5,2) criado/os para serem os herdeiros do domínio de Deus sobre a terra. Representantes de Deus não serão os reis, os sacerdotes, os grandes, mas o homem e a mulher. Ídolos nunca mais!

Os valores presentes nestas páginas bíblicas têm muito a ver com os valores presentes na vida quotidiana dos povos da Amazônia. Trata-se de estabelecer um diálogo atento e humilde, na atitude evangelizadora de Paulo que poderíamos assim parafrasear: Fazer-nos índios com os índios, caboclos com os caboclos, negros com os negros, ribeirinhos com os ribeirinhos, seringueiros com os seringueiros, fazer-nos tudo a todos e a todas.

Este imaginário de vida e de salvação inspirou os profetas que proclamaram as promessas de Deus ao seu povo sofrido:

Vou criar novos céus e nova terra... Já não haverá ali criancinhas que vivam apenas alguns dias, nem velhos que não completem a sua idade... Construirão casas para nelas habitarem, plantarão videiras e comerão de seus frutos... Os meus eleitos comerão eles mesmos o fruto do trabalho de suas mãos... (Is 65, 17-25).

É assim que o jardim vai entrar em nossas casas e no nosso quotidiano e o sinal da paz e da vida será descansar, esposos, filhos e filhas, debaixo das vinhas e das figueiras (Mq 4,4; Zc 3,10; 1Mc 14,12).

É a "terra sem males" do mundo indígena.

\section{Ecumenismo, economia, ecologia}

A interação entre espiritualidade ecocentrada e espiritualidade da libertação nos leva a ampliar nossa reflexão sobre o que devemos entender por ecologia.

As palavras economia, ecologia e ecumenismo vêm todas da língua grega e se originam do verbo "oikeo": habitar. O particípio presente passivo feminino deste verbo é "oikoumenen": a realidade que está sendo habitada. O substantivo derivado é "oikoumene".

Esta palavra foi, logo, entendida como "todo o universo habitado", "toda a sociedade humana", "toda a terra", A esta palavra costuma-se dar uma dimensão universal.

Quase todas as vezes que a palavra oikoumene aparece nos textos bíblicos ${ }^{12}$ tem a conotação que lhe é dada no texto clássico:

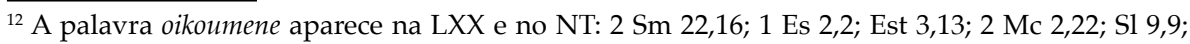
17,$16 ; 18,5 ; 23,1 ; 32,8 ; 48,2 ; 49,12 ; 71,8 ; 76,19 ; 88,12 ; 89,2 ; 92,1 ; 95,10,13 ; 96,4 ; 97,7,9 ;$ Odes 7,45; $\mathrm{Pr}$ 8,31 ; Sb 1.7; Is 10,14, 23; 13,5, 9, 11; 14,17, 26; 23,17; 24m1, 4; 27,6; 34,1; 37,16, 18; 62,4; Jr 10,12; 28,15; Lm 4,12; Ep. Jr 1,61; Dn 2,38; 3,2, 45; Dat 3,45; Mt 24,14; Lc 2,1; 4,5; 21,26; At 11,28; 17,6, 31; 19,27; 24,5; Rm 10,18; $\mathrm{Hb} 1,6 ; 2: 5 ;$ Apoc 3,10; 12,9; 16,14.
} 
De Yaweh é a terra e a sua plenitude, o mundo (oikoumene) e aqueles que nele habitam (Sl 24,1).

É, porém, interessante notar que a palavra oikoumene nunca aparece nos textos paulinos ${ }^{13}$ e é muito pouco usada no Segundo Testamento. Apesar do seu esforço em dialogar com o mundo grego, Paulo não usa esta palavra, preferindo usar, como em geral no Segundo Testamento, a palavra "kosmos"14.

Para os gregos a palavra oikoumene indicava, quase sempre, as populações que eram conectadas com o projeto político e comercial grego. Os bárbaros e os escravos não faziam parte da oikoumene.

Diga-se o mesmo para o império romano: oikoumene eram as nações que formavam o império, os povos tributados e comercialmente explorados pelo império ${ }^{15}$. Oikoumene, que parecia ser uma palavra inclusiva, era, na verdade, um forte elemento de exclusão. Uns eram oikoumene e muitos outros não.

Esta ambiguidade justifica a ausência desta palavra nos textos paulinos. Suas afirmações são claras:

Eu sou devedor tanto a gregos como a bárbaros, tanto a sábios como a ignorantes $(\operatorname{Rm} 1,14)$

Não há grego, nem judeu, circuncisão, nem incircuncisão, bárbaro, cita, escravo ou livre; mas Cristo é tudo em todos $(\mathrm{Cl} 3,11)$.

O Reino de Deus é uma coisa, a oikoumene é bem outra (ver também, Mt 24,14; Lc 4,5; 21,26): a ela deve ser anunciado o evangelho do Reino. ${ }^{16}$

Por que fiz estas considerações? Porque do verbo oikeo, derivam, também, as palavras oikia, oikos: habitação, casa, residência, lugar habitado, família.

A oikoumene é o conjunto das "casas", de todos os espaços que são habitados. Não há como separar o universal do local.

Aqui, porém, precisamos levar em consideração que casa, também, nunca foi sinônimo de igualdade entre os que habitam nela. Tem o homem e tem a mulher, tem o pai e tem o filho, tem o amo e tem o escravo.

\footnotetext{
${ }^{13} \mathrm{Rm} 10,18$ é uma citação dos LXX.

${ }^{14}$ A palavra oikoumene aparece 15 vezes no Segundo Testamento, enquanto a palavra kosmos aparece 150 vezes.

${ }^{15}$ Com este sentido a palavra oikoumene aparece, por exemplo, em Lucas 2,1 e em Atos 17,6 e 19,27.

${ }^{16}$ Temos que dizer que também a palavra kosmos, sobretudo em João, não tem o significado global de mundo, de universo, mas identifica as forças negativas que se contrapõem ao Reino É bom lembrar que esta ambiguidade se mantém, também, nos tempos atuais: a palavra ecumenismo - que deveria significar a atitude de encontro e de respeito entre todos os que vivem no mesmo mundo habitado - é quase sempre usada para falar da unidade das igrejas cristãs, excluindo do ecumenismo as demais expressões religiosas. Para estas foi preciso criar a palavra macro-ecumenismo: uma evidente redundância.
} 
As relações internas da casa são determinantes, podem ser igualitárias:

Não há judeu nem grego; não há servo nem livre; não há macho nem fêmea; porque todos vós sois um em Cristo Jesus (Gl 3,28).

Ou as relações dentro da casa podem ser de domínio, de governo:

Todos os escravos que estão debaixo do jugo estimem os seus senhores dignos de toda a honra, para que o nome de Deus e a doutrina não sejam blasfemado (1Tm $6,1)$.

As mulheres idosas (...) ensinem as mulheres novas a serem prudentes, a amarem seus maridos, a amarem seus filhos, a serem moderadas, castas, boas obreiras de casa, submetidas a seus maridos, a fim de que a palavra de Deus não seja blasfemada (Tt 2,3-5).

Quanta diferença entre o homem: dono/patrão da casa (oikodespotes) e a mulher trabalhadora da casa (oikourgous)!

É por isso que precisamos definir qual é a nossa "ecologia"17. Qual é o nosso discurso sobre a casa? De que casa nós estamos falando quando usamos a palavra ecologia?

Ecologia é dizer o que pensamos da nossa casa, como um todo. Quase sempre - e, nisso, empresários e ambientalistas costumam ser iguais - se entende ecologia como a nossa relação com a natureza, com o meio ambiente, podemos dizer com o nosso quintal. Discute-se o ambiente, discute-se como deve funcionar o quintal, mas não se discute que tipo de casa nós queremos.

Tem muita gente que, quando pensa em casa, não pensa numa casa comum, onde todos sentam ao redor da mesma mesa e repartem o mesmo pão, sem distinção; continuam pensando em "casa grande" e em "senzala"18".

Muitos falam em ecologia, mas se preocupam só com o quintal, com a natureza, com o ambiente que está fora da casa e, assim, falam em desenvolvimento sustentável, em defesa da terra e da água, mas continuam sem por em discussão a "casa grande" dos países mais ricos, das classes dominantes, das corporações industriais e financeiras, das elites privilegiadas e corruptas que engordam às custas de uma imensa, incalculável "senzala" que é explorada, oprimida, excluída.

Progresso, crescimento, desenvolvimento, para eles, significa entrar a fazer parte da casa grande, nem que seja como uma remediada classe média. A senzala ainda não saiu da cabeça de muitos de nós.

\footnotetext{
${ }^{17}$ Ecologia vem do grego: oikos = casa e logos = discurso. Diga-se o mesmo da economia que vem de oikos = casa e nomos = lei, norma.

${ }^{18}$ A casa do amo, do patrão e as moradias dos escravos.
} 
Precisamos nos converter, pois a economia (a lei, a organização, a administração da casa) vai depender da ecologia (de que casa estamos falando, em que tipo de casa queremos viver).

Se continuarmos a acreditar na casa grande ${ }^{19}$, teremos uma economia centrada na especulação financeira, nos monopólios industriais, na privatização dos serviços públicos - realidades estas que nada teriam a ver com a ecologia. Uma economia baseada no agronegócio, na monocultura, na mineração, nas exportações de matéria prima, no trabalho escravo, na concentração fundiária, nas sementes transgênicas, nos agrotóxicos.

Na melhor das hipóteses, faremos os estudos de impacto ambiental e as audiências públicas para tentar minimizar e corrigir a inevitável destruição que será compensada com poucas esmolas sociais, com uma oferta temporária de empregos, com a promessa de impostos que, depois, serão sempre descontados e com algumas medidas compensatórias regularmente abatidas do imposto de renda devido.

A casa grande ficará com os produtos e os lucros; a senzala ficará com o trabalho e as migalhas da assistência social e o quintal será devastado. Os pobres perderão a terra! A terra perderá a vida!

A verdadeira e mais importante diferença está na maneira de olhar a terra, a água, a natureza: socialistas e capitalistas enxergam tudo isso como matéria prima que adquire seu valor ao virar mercadorias que deve ser comercializada e privatizada, deixando de ser direito e bem coletivo. Nós queremos olhar a terra, a água, a natureza como a nossa casa, a nossa mãe e fonte de vida para todas as criaturas.

Nós entendemos que a luta pela terra é, hoje de maneira especial, luta pela TERRA, com a T maiúscula. É a luta pela vida do planeta que é violentamente ameaçada por um falso conceito de crescimento, desenvolvimento, progresso e por uma ainda mais falsa ideia de que os recursos naturais são infindáveis.

Aprender com as comunidades tradicionais o que significa uma casa feita tenda comum, aberta a todos, não significa atraso. Significa vida abundante para todos e todas.

Lutar pela terra e pela vida da Terra é um imperativo ético que testemunha nossa fidelidade à memória, à tradição, à ancestralidade, às nossas raízes. É a fidelidade aos pobres de Deus.

Lutar pela terra e pela vida da Terra é uma exigência que testemunha nossa relação sagrada com a terra, nossa mãe, nossa amiga, nossa amante, à qual devemos "servir" e "obedecer", pois dela todas as gerações terão vida em abundância. É a fidelidade à terra que é de Deus e de todos e todas nós.

Lutar pela terra e pela vida da Terra é uma obrigação que testemunha a fé no nosso Deus. Da ecologia, depende não só a economia, mas,

${ }^{19}$ Não vamos esquecer que a palavra faraó significa, literalmente, "casa grande". 
também, a teologia. A casa que pensamos e queremos determina qual é o Deus ao qual nossa casa deve ser fiel. É a fidelidade ao Deus dos pobres.

Este testemunho de fidelidade ao Deus dos pobres, aos pobres de Deus e a terra que é de Deus e de todos, levou inúmeras companheiras e companheiros a amar até o fim, até derramar seu sangue. São os mártires/ testemunhas que as igrejas nunca devem esquecer.

\title{
5. Ecologia e eclesiologia
}

Nossas igrejas, muitas vezes, seguiram e seguem a lógica da casa grande e da senzala que deturpou nossas relações: templos, altares, sacrifícios, hierarquias, governos são coisa da casa grande, de um sacro-negócio blasfemo e diabólico, o mesmo que, aliado ao império opressor, condenou à morte Jesus de Nazaré.

O evangelho do Reino de Deus nos convida a fazer a diferença dentro e fora da igreja: casa, mesa, pão repartido e serviço devem substituir templos, altares, sacrifícios e dominações. Foi isso que Jesus celebrou na ceia pascal. É isso que devemos continuar testemunhando em memória dele e de seu martírio.

Pão repartido quer dizer terra repartida, bens partilhados, luta contra toda concentração, contra o latifúndio excludente, devastador e violento. É a defesa da vida contra todas as formas de escravidão, mesmo as que são mascaradas de crescimento e são chamadas de mercado.

Pão repartido é crer que nossa casa é uma oca comum ou, usando a linguagem bíblica, uma "tenda". Nem palácios, nem templos, nem quartéis, nem armazéns, nem bancos, nem especulações financeiras.

Vamos repetir uma vez mais: a palavra faraó significa "casa gran$\mathrm{de}^{\prime \prime}$.

O nosso Deus, o Deus dos nossos pais e das nossas mães, o/s deus / es dos nossos povos ancestrais nunca estará na casa grande, apesar dos templos gigantescos que eles construíram e continuarão construindo.

Iahweh será sempre o Deus dos hebreus ${ }^{20}$, dos marginalizados que só querem viver em paz, podendo desfrutar do fruto da terra e do seu trabalho, do pão e do vinho que ofertamos ao Senhor para que seja sempre de todos e de todas.

\author{
Sandro Gallazzi \\ gallazzi46@gmail.com
}

\footnotetext{
${ }^{20}$ Segundo muitos estudiosos, o termo hebreu vem de hapiru que na literatura egípcia indicava alguém que estava à margens da sociedade, muitas vezes, com a conotação negativa de bandido, assaltante, mercenário etc.
} 